\title{
INTEGRATED ADOPTION OF MANAGEMENT SYSTEMS: A DUAL SWORD
}

\author{
Asad Ur REHMAN ${ }^{*}$, Muhammad SHOAIB ${ }^{b}$, Roman ZÁMEČNÍK ${ }^{c}$,

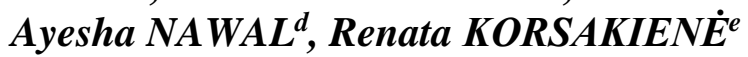 \\ ${ }^{a, d}$ University Sultan Zainal Abidin (Business and Management), Malaysia \\ b,c Tomas Bata University in Zlín (Management and Economics), Czech Republic \\ ${ }^{e}$ Vilnius Gediminas Technical University (Business Management), Lithuania
}

\begin{abstract}
This study aims to investigate the middle management perspective for integration adoption of ISO management systems and consumer awareness of organization implication of ISO systems ultimate effect on purchase intention. IMS includes the combine adoption of ISO 9001:2008, 14001:2004 \& OHSAS 18001:2007 in dairy industry in Pakistan. This study firstly explores integration adoption of IMS systems and also for effective management of cost and benefits for an organization. At second stage study measure the awareness about ISO systems its influence their purchase intention. Study is based on mix-method approach, exploratory and explanatory in nature. Population were the employees of dairy sector and data collected from 340 middle management employees. At first stage, thematic analysis performed for understanding the management perspectives and second stage structural equation modeling used to examine the relationship ISO awareness among consumer its influence on their purchase intention. Study explored that middle management have positive perspective towards integrated adopt of ISO will reduce cost. Moreover, awareness of IMS systems have significant positive influence on consumer purchase intention. However, customer perceive quality, brand image, brand attitude and brand preference mediate the relationship between awareness of IMS systems and online purchase intention.
\end{abstract}

KEYWORDS IMS; perceived quality; brand image; brand attitude; purchase intention

DOI: 10.24818/IMC/2021/01.04

\section{INTRODUCTION}

In dynamic environment both at national and international markets with intense competition, for growth firms should think proactively to design their strategic objective. Management systems are peeler to develop successful strategy and management systems are two-way swords, by integrational adoption of these systems companies reported 85\% external benefits and 95\% external benefits (Intertex, 2020). Firm's existence in competitive market, management systems are emerged as tools for competitive competence. Consistent improvement in quality and customer satisfaction reply on strategic usage of systems as dual beneficial tool for managerial decision making as well as for marketing perspectives to hunt and retained customers (Wu \& Chen, 2011). The strategic importance for adoption of managerial systems is to improve customers perceive quality, global customer recognition of product, organization and brand image (Nuland, 1990; Wu \& Jang, 2014). Majority of benefit produce by systems drained, which

\footnotetext{
*Corresponding author. E-mail address: shoaib@utb.cz
} 
can be utilized to improve stakeholder and customer perceived image of firm (Poksinska \& Dahlgaard, 2003b). ISO certifications firms able to attract, retention and improve customer's loyalty and gain sustainable organizational success for longer tenure (Yang, 2011).

Rare, studies have been investigated the linkages between management systems and customer relationship management, and customer perspective still under-investigated to predict the ISO certified products firms influence on consumers brand attitude and purchase intention. Questions need to answers, 1). Does these certification really improve corporate image? 2). Does ISO certification also effect brand attitude, and purchase intention. These black box required solutions to evaluate in relation ISO with certifications awareness on consumers brand attitude and purchase intention in Pakistan. It has been investigate that level of ISO certification awareness among customers improve perceive quality and brand image directly and mediate the relationship with brand attitude, customer intention toward purchasing a certified product. Preference of products with ISO certifications attract customer for buying behaviour (Wu \& Jang, 2014). But convenience product got less attraction those have already implement the ISO certification. Moreover, those firms implement integrated management systems (IMS), gain known benefit of that may enhance product quality, working environment and worker safety and at the most corporate or brand image. But the impact of IMS on brand attitude, brand preference and customer purchase intention still to address in empirical literature. Thereby, present study contributes to the literature in following ways. First, based on IMS adoption, this study explores the middle management perspectives towards adoption of IMS (QMS 9001:2008, EMS 14001:2004 and OHSAS 18001:2007) certification. Also, gave attention to convenience goods (dairy products). Second, based on theoretical conceptualizations to empirically investigate the ISO certification awareness linkages with brand attitude and consumer purchase intentions. Moreover, practically study measure the ISO certification implications for firms to promote the IMS certification in customer to gain distinguish image in customer mind.

\subsection{ISO Quality Management System 9001}

World war II brings a lot of manufacturing difficulties in British bomb industry, to address this problem standard rule were develop to documented every manufacture activity that standard known as BS 5750 (Kaizen Consulting Group, 2013). In 1987 British formed International standard organization to adopt BS 5750 as manufacturing standard got fame as ISO 9000. ISO 9001 was formed to assured the quality of manufacturing processes and new product development. (Low, 1998) The proactive purpose was to provide perceive quality insurance in the mind of the buyer by the producer of the product. (Low \& Fong, 2002; Peng \& Kwang, 2011) This standard re-evaluates and upgraded in 1994 and most recent gradation. ISO 9001:2000 principles, customer satisfaction, leadership, procedural approach, Systematic management, Continuous improvement, Decision making over facts, Collaborative benefited relation. The business world got new re-launched version of 9001:2008 which is familiar to previous one with changes in requirements for maintain QMS (Kaizen Consulting Group, 2013). Quality management system 9001:2008 based on following principles namely customer satisfaction, leadership, people involvement, procedural approach, systematic managerial approach, continuous operational improvement, decision making on facts and mutual beneficiate relationship with suppliers. Whereas, for ISO EMS 9001: 2008 firms required following steps; i.e. firm has to escalate is capabilities to produced product that relevant to customer expectation by following legislation and adoption of continuous improvement that helps to improve satisfaction level of customer (Kaizen Consulting Group, 2013). 


\subsection{ISO Environmental Management System 14001}

British standard institution with stakeholders develop the first environmental system BS 7750:1992 that deal with environmental issues. After that ISO technical experts develop environmental system 14001:1996. As per all ISO systems reviewed, EMS 14001 priorly reviewed between three to five years. The revision made not for major changes in system but to ensure compliance with other management systems (Whitelaw, 2004). Moreover requisites of ISO 14001 are environmental policy making, Identify environmental aspects and impact evaluate over environment, develop legal rule and regulation require maintaining the system, develop and maintain environmental policy objective and target, apply documentation system which includes operational, training and emergency deal manuals, monitor and measure operational work, conduct internal environmental audit and revision of system for continual improvement (Whitelaw, 2004). EMS 14000 series deal with environmental issues related to institutions. This series provide the instruments to identify and evaluate the environmental concerns in organization and solution to prevent environmental issues and improve environmental performance of workplace (ISO, 2013). EMS 14001:2004 and 14004: 2004 intension for environment concerns. EMS 14001 not provides any procedure to maintain environment although provide structure design to manage effective system. Implication of EMS 14001 generate guaranty for stakeholders as well for management that environmental influence is check and control. ISO 14000 series deal with how institution operational activities effect over environment could be minimized, Implementation of environmental concern legislation and other related requisites, Continuous improvements in operational activities to minimal the effect on environment. ISO EMS 14001 would help to reduce the cost and effective of handling of waste, effective management of energy and raw material, enhancement of institutional image among stakeholders and reduction in available cost (Peng \& Kwang, 2005).

\subsection{Occupational Health and Safety Assessment System 18001}

OHSAS 18001 identify the hazards and risk during the working practices that face by the workers (Whitelaw, 2004). OHSAS 18001 launched 1999 to business world which is selfmaintain management instrument, similar to EMS 14001 without prescribed set of health and safety route plan (Peng \& Kwang, 2005). Whereas, firms those want to implement system can mold it as per specific requirement. OHSAS has same framework as EMS can sense making related to organizational objective (Kaizen Consulting Group, 2013). OHSAS revised in 2007 and new version available for organization under the head ISO, expert team working with BSI to transfer OHSAS 18001 into OH\&S management system, team work with interest holder parties to form GMS as like QMS 9001:2008, EMS 14001: 2004 (ISO, 2013). There are some general requirements for implications of "Occupational Health and Safety Management Systems, 2007": 1). OH\&S policy, 2). Planning includes, Identify hazard, assess the risk, legislation and other requirement and $\mathrm{OH} \& \mathrm{~S}$ objectives, 3). Implement \& operational work activities includes, i). Resources, responsibilities, authorities, responsibilities, ii) Competences, trainings, awareness requirements. iii). Organization communication, employee's participants and consultancy, iv). Documents and control over documentation, v). Operational activities, preparation for emergency and responsiveness, 3). Checking \& lastly, 4). Managerial review.

\subsection{ISO Systems Comparison}

QMS, EMS, OHSAS formed with such thinking to implement them integratedly. But some distinguish points still there, QMS and OHSAS beneficiaries are distinguish as well, QMS 
provide ultimate benefit to consumer of the product or services and employees are benefit by the OHSAS. But EMS influence positively both employees and consumer of product or services. QMS focus on product or service quality improvement, EMS deal with reduction of environmental impact caused by operational activities of organization (Peng \& Kwang, 2011). Whereas, OHSAS deal with employee's safety \& health during the performance of operational activities. QMS and EMS have similarities because both deal with how to manufactured a commodity, secondly certifications are awarded by ISO but implication performed by third entity, thirdly systems are audited under 19011 audit standards.(Griffith, 1995; Peng \& Kwang, 2005) It evidenced that integrated managerial implication of quality concern, environment improvement and health \& safety is systemic theory.

\subsection{ISO Certification Awareness}

ISO certified product considered as quality issured brands (Wu \& Jang, 2014). Firms with ISO certification, products got opinion as quality products (Nuland, 1990). Institution with any size adopt ISO systems that provide better information to consumer to make effective decision (Conti, 1999; Elmuti, 1996). ISO certification influence customer understanding in organizational view that cause favourably satisfaction of customer by the use of certified brand (Zelnik et al., 2012). ISO certified products improve brand image, helps to improve market share, gain employees' involvement, quality enhancement and overall consumer satisfaction with brand (Gotzamani, 2010; Poksinska \& Dahlgaard, 2003a). Study also revealed that customer awareness with ISO certified product may improve customer satisfaction, attract \& retain customer, enhancement of efficiency, improve work environment and reduce harmful effect of product packaging, better market response, reduce waste by application ISO certification (Payner \& Porter, 1991).

\subsection{Perceive quality}

Awareness of ISO certification in customer increase the perceive quality in the mind of customer (Wu \& Jang, 2014). Study argued that perceived quality is attribute in compare to the competitive product to fulfill the customer requirement (Monroe and Krishnan, 1985). Perceived quality is overall understanding of product by customer (Lin \& Lu, 2006). The theoretical understanding develop in the mind of customer and value of quality vary for every entity (Yu, $\mathrm{Wu}$, Chiao, \& Tai, 2005). Perceived quality is proactive image of product or services in customer mind and information source is salesperson, media, or an event (Aaker, 1996a, 1996b). Customer evaluation is on the base of perceive quality and it include all attributes of product and service.

\subsection{Brand Image}

ISO certifications considered key element of marketing that enhance brand image in consumer understanding (Wu \& Jang, 2014). Study proposed that brand image is outer source of perceived quality understanding of entity by customer and it manage perceived qualityin consumer undertaking because deeply held impression on product success (Richardson, Dick \& Jain, 1994). Brand equity development of any product branding lead by brand image (Keller, 1993). Moreover, functional and abstract brand component associations are two major factors of brand image Study measure that firms and brand image are cohesive which emerged due to association of organizational innovation and social responsibility (Aaker, 1996a, 1996b). 


\subsection{Brand Attitude}

Positive attitude about brand in customer mind cause by ISO certification (Wu \& Jang, 2014). Study argued that consumer responsiveness and exploration of brand is known as brand attitude (Keller, 1993). Brand attitude is acceptance of product over competitive brands that make sense due to certain media message of evaluation of particular situation (Mackenzie, Lutz, and Blech, 1986). Another study revealed that consumer brand attitude rely on relationship between elements and benefits of brand, exploration of brand elements and confidence over brands need fulfillment (Fishbein \& Ajzen, 1975). Brand attitude is consumer description in more partial manner not full as sense of awareness and need fulfillment of consumer. Study concluded that brand attitude is self-perception of consumer regarding particular brand (Lane, Jacobson, 1995). Another study conducted to measure brand attributes to evaluate the brand attitude (Morris, Woo, Geason \& Kim, 2002).

\subsection{Purchase Intention}

Consumer responsiveness for potential buying is positive for brands with ISO certification (Wu \& Jang, 2014). Purchase intention is consumer personal evaluation what decision will made related to buying of certain brand, also discussed that attitude is complementary rule but insufficient rule for intention exploration (Blackwell, Miniard \& Engel, 2001). Attitude and behavioral association is mediate by the intention for object (Blackwell et al., 2001; Solomon, 2002).

\subsection{Conceptual Framework}

The conceptual framework is presented in figure 1 .

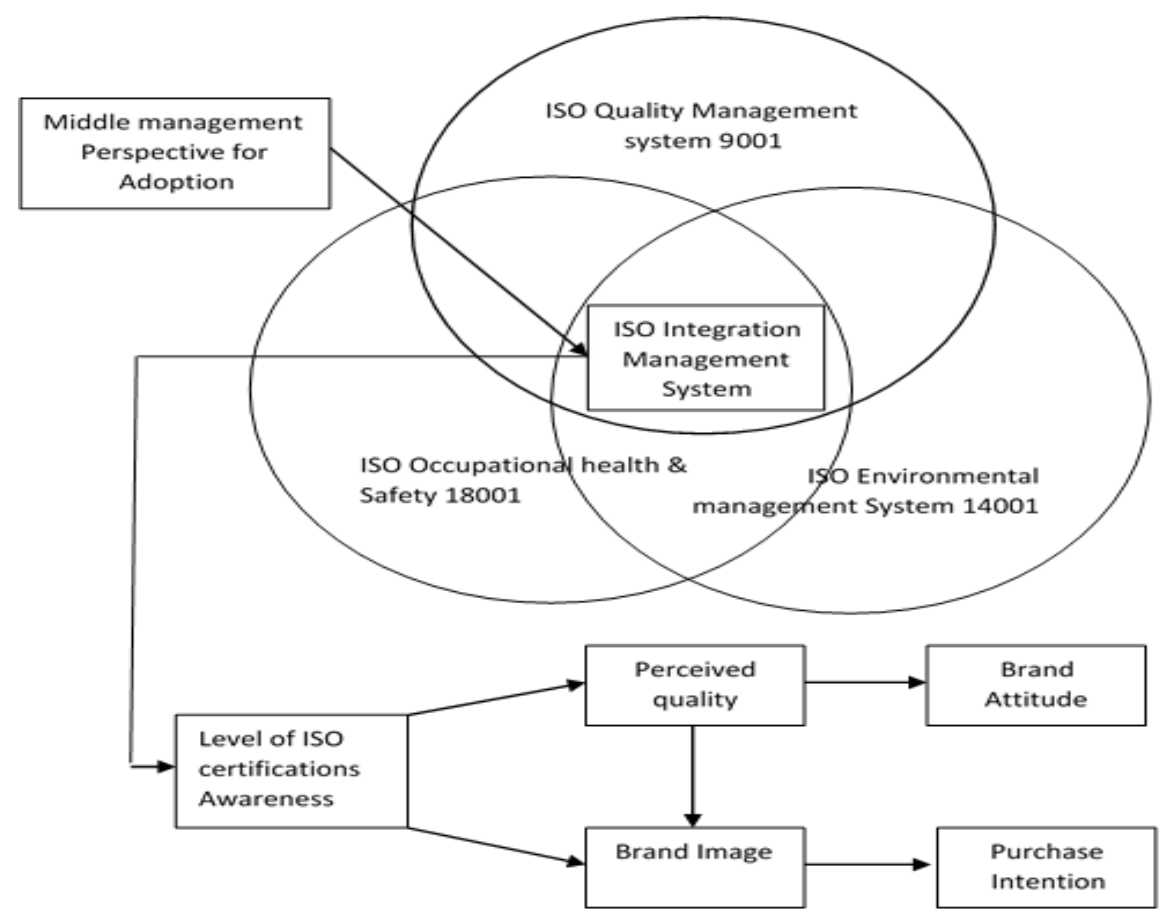

Figure 1. Research Framework 


\section{METHODOLOGY}

Study based on mixed-method approach, firstly as intend to explore the middle management perspective for adoption of integrated management system (i.e. Quality management system 9001; 2008, Environmental management system 14001; 2004 and Occupational health and safety assurance system 18001; 2007 integratedly). Secondly study aims to measure the consumer level of ISO certifications awareness effect on consumer purchase intention and brand attitude mediate by perceive quality and brand image. Research framework of this study based sequential mixed method approach. First, integration adoption of ISO systems explore from middle management perspectives. Second, level of ISO certification awareness among customers effect on their brand attitude and purchase intention.

At first stage, 20 interviews were conducted with the employees of middle management of "Engro foods". Thematic analysis conducted to understand the middle management point of view about integration adoption of ISO management systems. The data from the in-depth interviews was transcribed by make use of the recordings and the field notes. Transcriptions were read, reread to extract meaning out of them. Categories and themes generated based on the evidence patterns in the data. Internally convergent categories and themes identified. Themes streamlined with the objectives of the study. This was more like a stage of data reduction as totally divergent views and irrelevant data was ignored. Major categories identified under a theme given a title (code) that gave the overview of the related data, helped in the interpretation stage. All the data organized, after coding was reviewed again and again to make sense out of it and develop linkages. The data was interpreted to reach at the conclusion.

Second, cross-sectional survey questionnaire used to collect data for quantitative part of study, 400 questionnaires distributed randomly among the employees of "Engro food", because they are also consumer of their company products and well aware of implementation of ISO management systems. Data collected from employees done intentionally to avoid the interference from the influence of external factors, as they were from homogeneous background as sampling subjects. Pilot study was conducted with 20 employees, aim to identify the core language concern and mitigate the problematic issues that may effect the results of final study. The final survey spanned on three weeks, a tool of 400 questionnaire distributed and 384 was returned, and valid response rate was 96\%. Data was collected on 5-pointed Likert scale explicit the respondent strength of agreed or disagreed response with statement. Pilot test output revealed that value of Cronbach's alpha for each construct is greater than 0.72 . The exploratory factor analysis revealed that the eigenvalue of single was $>1$, the cumulative explained variance of single was greater than 5, and the factor loading of each question was greater than 0.6; these results indicated the high convergent validity of the questionnaire (Kerlinger, 1978).

\subsection{Measures}

Previously established scales were used to measure the constructs, survey comprised on seven section, first section is demographic constructs of study, second section comprised on level of ISO certification awareness measure with four times adopted with Cronbach alpha value of 0.804 from (Wu \& Jang, 2014). Third section comprised on Perceived quality adopted with four components i.e. performance, durability, value and newness with 12 loaded items from to (Brucks \& Zeithaml, 1991; Grewal, Monroe \& Krishnan, 1998). Fourth, brand image measured with three component i.e. functional image, abstract image and organize image, adapted from (Aaker, 1996a, 1996b; Biel, 1992). Fifth, brand attitude measured with five items adopted form (Morris et al., 2002). Sixth, purchase intention measured with three items adopted from (Grewal, Monroe \& Krishnan, 1998). 


\subsection{Qualitative data analysis}

\subsubsection{Importance of ISO systems for Organization}

Present study objective is determine the importance of ISO systems for the organization and how these systems help to be a best player of competitive market. The analysis of study asserted that these systems play important role Employer branding as well product brand management. One of the interviewee expressed "Organization maintain QMS, EMS, OHSAS to improve the image of the product in understanding of every stakeholder, consumer perception for product and institution is that product is match with quality standard and also environment friendly and its safer place for work" The response of other interviewee's support the idea that Employer branding and product brand management influence by implementation of ISO systems.

"For company that is international and export its product in globally competitive market has to maintain ISO systems because of global clients having so much competitive brands available those passed out quality assurance certification, consider as environmental friendly product and production place environmental hygienity, implement protected measure for people who work closing with production process, health assurance and protection from accident and harmful effect of chemicals, client make sure that your origination follow the legislation regarding labor. If your organization maintain These ISO standard then your products are able to compete in intensive competition market and develop positive perception and image of brand in customer evoke set". Data gave the impression that ISO systems have significance relationship with marketing of product and helpful to shape consumer behaviour regarding the brand. It may be theunique capability of product to get advantage over brands in competition. For positive word of mouth from every stakeholder of organization ISO standard portray a major contribution.

\subsubsection{Middle management perspective for Integration of (QMS 9001:2008, EMS: 2004, OSHAS 1800)}

After got information regarding the importance of ISO management systems, interviewee's asked about the integrated implementation of ISO standards. One of the respondent expressed her view "As per knowledge; organization have to start with partial integration, means to say separately manage all the management systems but the common requirement of them maintain on single or integrated manual, disadvantage of partial integration is that separate work over each management system require extra force of expert for implementation and maintenance. So if organization have resources straightway go for full integration, develop an integrated manual of all systems, develop the cross functional teams of experts to work collaboratively over all systems. After developing the integration manual arrange audit and got integration certification from ISO. It's quite easy to maintain single system to insure the quality of product, environmental performance of organization and follow labour legislations. When you have a separate management systems its look like that your workforce working not for you institution but for the auditing firm because the separate audit for each system conduct every year, the performance and routine activities to complete basic task are effect" The view of other respondents similar so data gave impression that two type of integration can be possible partial or full but middle management believe that full integration more beneficial for organization because the complexity to maintain systems separately eliminated and more collaborative working for these systems enhance the product quality, environmental performance and health and \& safety standards.

\subsubsection{Cost and Benefits of Integration Management systems}

In the light of respondent view there is a strong evidence that "it's a onetime investment to gain Integration management system but benefits for organization are too many, firstly; the headache 
of separate audit for each system eliminate and there is one audit held in year. Organization hire large force to maintain these systems because integration helps to reduce the size of staff related to ISO standards and develop just one cross functional team of expert that work together to assure the effectiveness of standards. The routine activities of the worker not effected as much in separate maintenance of all systems. Secondly the complexity of procedure are eliminate and burden of extra work reduce for middle management. The paper work reduce to the just one manual from three and the cost of integration system adoption is 2 time less then separate systems" The other views of respondent follow the same sense and themes, so the cost on maintaining these systems include in the overall cost of production by the implementation of IMS the production cost reduce that give organization another capability to compete over cost in global market. Spend this cost saving over product quality improvement marketing tactics to inform customer that organization brands are quality conscious, environmental friendly and produced in hygienic environment.

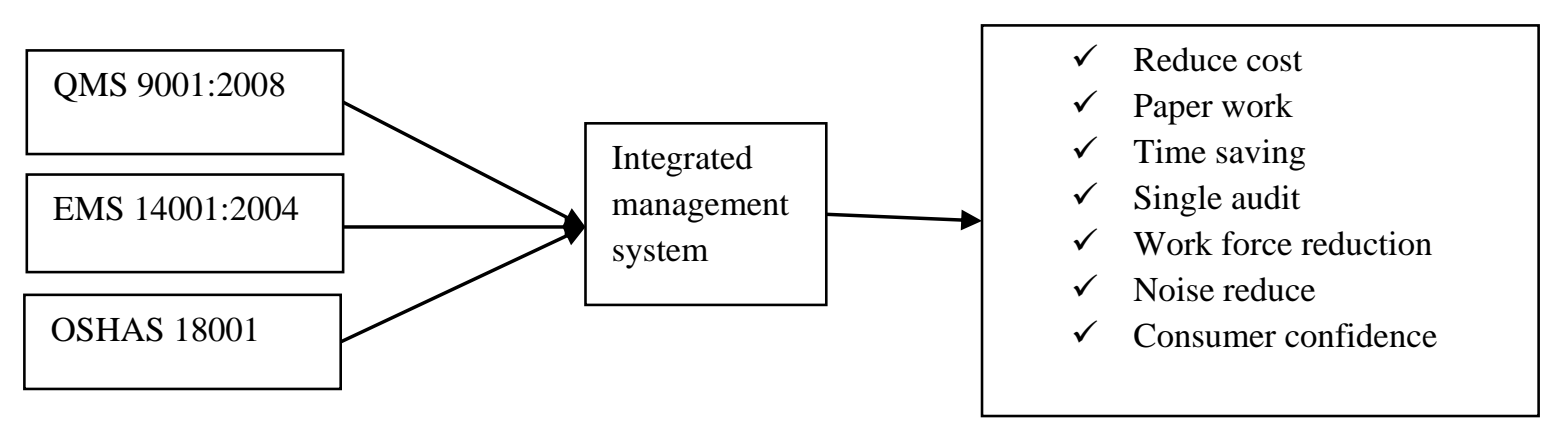

Figure 2. Middle management Perspectives elaborated by the following model developed

\subsection{Quantitative analysis}

\subsubsection{Descriptive Statistics}

The impression of data analysis shows that most of the respondents of study were male and $66 \%$ respondent were between the ages of 31 to 40 years. The education pattern varies but most of the respondent were graduate, master and got technical education. The data pattern explain that respondent have experience between 6 to 13 years. Most of respondent income greater than 50,000 and above. The demographic results show that respondent with higher education, greater working experience and mature age have a greater awareness about the ISO standards and influence over product quality, environmental performance and health \& safety requirements of workers. Overall how these standards structure the organization affords to product quality product for market.

\subsubsection{Common Method Biases}

The nature of study is cross-sectional and data collected from single source for the endogenous and exogenous constructs. So assessed the common method variance (CMV) estimation via Harman's single-factor test (Podsakoff \& Organ, 1986; Podsakoff et al., 2003). Purpose to measure the amount of spurious prevails among the constructs because of data collection from single source. An exploratory factor analysis performed for all the constructs, items measured 
that the first three factors collectively counted for $59.941 \%$ for the variance in constructs with eigenvalue greater than 1 . The first factor accounted for $29.96 \%$ of the variance that eradicate the chances of data affected due to common method bias issue.

Table 1. Demographic analysis

\begin{tabular}{llll}
\hline Demographics & & Frequency & Percent \\
\hline Gender & Male & 159 & $79.5 \%$ \\
Age & Female & 41 & $20.5 \%$ \\
& $25-30$ & 29 & $14.5 \%$ \\
& $31-35$ & 61 & $30.5 \%$ \\
& $36-40$ & 70 & $35.5 \%$ \\
Education & $41-45$ & 30 & $15 \%$ \\
& 45 -above & 10 & $0.5 \%$ \\
& Graduation & 59 & $29.5 \%$ \\
Experience & Master & 71 & $35.5 \%$ \\
& Post-graduation & 19 & $9.5 \%$ \\
& Technical education & 51 & $25.5 \%$ \\
Income & $3-5$ & 37 & $18.5 \%$ \\
& $6-9$ & 73 & $36.5 \%$ \\
& $10-13$ & 39 & $19.5 \%$ \\
& $13-15$ & 51 & $25.5 \%$ \\
& $25000-35000$ & 0 & $0 \%$ \\
& $36000-50000$ & 32 & $16 \%$ \\
& $51000-75000$ & 68 & $34 \%$ \\
& $75000-99000$ & 57 & $28.5 \%$ \\
\hline
\end{tabular}

Source: Made by Authors

\subsection{Data Analysis}

\subsubsection{Measurement Model}

Data analysis performed via IBM SPSS-AMOS Graphics version 25.0. Two-step analysis technique used for Structural Equation Modeling (SEM) suggested by (Anderson \& Garbing's, 1988). At first stage, scales were evaluated via exploratory factor analysis as well as confirmatory factor analysis, the level of ISO certification awareness was first-order construct and four items $78.76 \%$ of variance. The perceived quality was confirmed as a high-order or multidimensional scale based on four components i.e. performance, durability, value and newness and first factor during EFA accounted for $42.39 \%$ of variance. The construct brand image based on three components emerged form EFA namely functional image, abstract image, and organize image but first factor counted for $39.56 \%$ i.e. less than $50 \%$ of required variance. The construct brand attitude recognized during EFA as first-order construct and five items accounted for $62.34 \%$ of variance. Lastly purchase intention also first order construct and three dimensions accounted for $78.56 \%$ of variance in a construct. The value of Cronbach's alpha coefficients for each construct prevail 0.789 to 0.924 value, signifying that all the first-order and multi-dimensional item scale are internally consistent.

In two-step model, further we first performed reliability and validity analysis by the measurement model followed by path analysis via structural model. The foremost important 
purpose of two-step techniques is to assessed the reliability and validate the measures prior to test their structural relationships. After EFA, confirmatory factor analysis (CFA) was performed to measure the validity of latent constructs.

The measurement model results conceded good model fitness, which confirmed that data are a good fit with the model. $\chi^{2 / \mathrm{df}}=1.651, \mathrm{SRMR}=0.037$, GFI $=0.958, \mathrm{AGFI}=0.934$, NFI $=$ $0.954, \mathrm{RFI}=0.940, \mathrm{CFI}=0.981 ; \mathrm{TLI}=0.975$; RMSEA $=0.043)(\mathrm{Hu} \&$ Bentler, 1999; Hair et al., 2014).

The reliability via composite reliability, convergent and discriminant validities of the constructs assessed to confirm the adequacy of the measurement model. Table 2 shows reliability via composite reliability (CR) values range from 0.84 to 0.94 and thus surpass the threshold level of 0.70 (Hair et al., 2011; Hair et al., 2014). Convergent validity examined with two standards recommended by Fornell and Larcker (1981): first the factor loading of each items of a study should be greater than threshold value of 0.70 secondly the value of average variance extracted (AVE) of each latent construct should greater than variance due to measurement error for the construct (i.e. value of AVE > 0.50). Factor loading of each item significant and greater than 0.70 and value of AVE also greater than 0.50 (Fornell and Larcker, 1981; Hair et al., 2011; Hair et al., 2014). Only one item (item of newness) component of perceive value counted factor loading below the cut-off value of 0.70 ; so the item delete before subsequent analysis. The AVE values assort form 0.708 to 0.889 , which exceed the required value of 0.50 , thus achieved both conditions for convergent validity. The discriminant validity assessed via two tests. First, the correlations among the constructs must be below the threshold value of 0.85 (Kline, 2005). Second, the square root of AVE must be greater than the correlations of a construct with other latent constructs in the model (Fornell and Larcker, 1981). The measurement model results fulfill both of the criteria (see Table 2 and Table 3 ). 


\section{Table 2. Statistics of Confirmatory Factor Analysis}

\begin{tabular}{|c|c|c|c|c|c|c|c|}
\hline Construct & Component & Indicator & Statement & SFL & CR & AVE & $\alpha$ \\
\hline \multirow{4}{*}{\multicolumn{2}{|c|}{$\begin{array}{l}\text { Level of ISO Certification } \\
\text { Awareness }\end{array}$}} & LICA1 & I have knowledge that Engro food has Passed ISO certifications. & 0.836 & 0.923 & 0.751 & 0.947 \\
\hline & & LICA2 & The message about the ISO certification is clear & 0.930 & & & \\
\hline & & LICA3 & The information about certification of this brand widely available to the public. & 0.896 & & & \\
\hline & & LICA4 & It is necessary for milk products to pass ISO certifications. & 0.798 & & & \\
\hline \multirow{11}{*}{$\begin{array}{l}\text { Perceived } \\
\text { Quality }\end{array}$} & Performance & PQP1 & I think Engro food product can satisfy my demand & 0.875 & 0.963 & 0.708 & 0.934 \\
\hline & & PQP2 & I think Engro food product appears as advertised. & 0.872 & & & \\
\hline & & PQP3 & I think the total performances of the Engro products are excellent. & 0.877 & & & \\
\hline & Durability & PQD1 & I think the quality of Engro food products are Stable. & 0.812 & & & \\
\hline & & PQD2 & I think Engro food products are reliable. & 0.910 & & & \\
\hline & & PQD3 & I think the containers of Engro products are safe and durable. & 0.923 & & & \\
\hline & Value & PQV1 & I think Engro food products can highlight personal characteristics. & 0.892 & & & \\
\hline & & PQV2 & I think Engro Food products are good to our health. & 0.917 & & & \\
\hline & & PQV3 & I think Engro food products have high added value. & 0.837 & & & \\
\hline & Newness & PQN1 & I think Engro food products are different from products of other brands. & 0.880 & & & \\
\hline & & PQN2 & I think Engro food products different from other products marketed earlier. & 0.925 & & & \\
\hline \multirow{9}{*}{$\begin{array}{l}\text { Brand } \\
\text { Image }\end{array}$} & Functional & BIFI1 & Products of this Brand have a good image. & 0.870 & 0.961 & 0.731 & 0.891 \\
\hline & Image & BIFI2 & Products of this brand provide honest label and description. & 0.874 & & & \\
\hline & & BIFI3 & Products of this brand provide good quality assurance. & 0.886 & & & \\
\hline & Abstract & BIAI1 & I feel happy and satisfied after purchase products of this brand. & 0.875 & & & \\
\hline & Image & BIAI2 & I have a position associated with this brand. & 0.833 & & & \\
\hline & & BIAI3 & Products of this brand create some related topics. & 0.789 & & & \\
\hline & Organize & BIOI1 & This company is creative. & 0.888 & & & \\
\hline & Image & $\mathrm{BIOI} 2$ & This company has good reputation. & 0.875 & & & \\
\hline & & $\mathrm{BIOI} 3$ & The image of this company increase consumer's confidence. & 0.798 & & & \\
\hline \multirow{5}{*}{\multicolumn{2}{|c|}{ Brand Attitude }} & BA1 & I think this Brand is interesting. & 0.794 & 0.924 & 0.708 & 0.872 \\
\hline & & BA2 & I prefer products of this brand. & 0.896 & & & \\
\hline & & BA3 & I think it is pleasant to use this brand. & 0.894 & & & \\
\hline & & BA4 & I think this brand is attractive. & 0.793 & & & \\
\hline & & BA5 & I hold positive opinion about this brand. & 0.824 & & & \\
\hline \multirow{3}{*}{\multicolumn{2}{|c|}{ Purchase Intention }} & PI1 & I will continue to purchase milk and ice cream products of this brand. & 0.991 & 0.960 & 0.889 & 0.821 \\
\hline & & PI2 & I will choose this brand as my first consideration. & 0.938 & & & \\
\hline & & $\mathrm{PI3}$ & $\begin{array}{l}\text { I am willing to recommend milk and ice cream products of Engro foods to other } \\
\text { people. }\end{array}$ & 0.898 & & & \\
\hline
\end{tabular}


Table 3. Descriptive Statistics and Evidence of Discriminant Validity

\begin{tabular}{lcccccccc}
\hline Construct & Mean & SD & VIF & 1 & 2 & 3 & 4 & 5 \\
\hline 1 & 3.39 & 0.99 & 1.361 & $\mathbf{0 . 8 5}$ & & & & \\
2 & 3.43 & 1.20 & 1.268 & $0.63^{* *}$ & $\mathbf{0 . 8 4}$ & & & \\
3 & 3.31 & 0.88 & 1.726 & $0.66^{* *}$ & $0.62^{* *}$ & $\mathbf{0 . 8 5}$ & & \\
4 & 3.15 & 0.72 & 1.877 & $0.26^{* *}$ & $0.31^{* *}$ & $0.16^{* *}$ & $\mathbf{0 . 8 4}$ & \\
5 & 3.43 & 0.95 & 1.124 & $0.55^{* *}$ & $0.66^{* *}$ & $0.56^{* *}$ & $0.27^{* *}$ & $\mathbf{0 . 9 4}$ \\
\hline
\end{tabular}

Note: 1 = Level of ISO Certification, $2=$ Perceived Quality, $3=$ Brand Image, $4=$ Brand Attitude, $5=$ Purchase Intention. The bold numbers in diagonal row are square roots of AVE. ** $p<0.01$

\subsection{Structural model}

\subsubsection{Assessment of research model fitness}

For the measurement of study proposed model fitness, followed suggestion of Hooper et al. (2008) for classification of goodness of fit indexes: (1) Absolute Fit Indexes; (2) Incremental Fit Indexes; and (3) Parsimonious Adjusted indexes. Goodness of fit indexes measure based on the suggestion of (Schreiber, 2008). At first stage, to confirm the absolute fit measures, study used four indexes i.e. (1) Chi-square/ degree of freedom $\left(\chi^{2} / \mathrm{df}\right)$, whereas the value of $\chi 2 / \mathrm{df}$ should not be greater than cutoff value 3.0; (2) RMSEA, whereas the RMSEA value of below 0.08 indications a good fit (Hu \& Bentler, 1999); (3) GFI, whereas a value of 0.90 or better indicator of a good fit (Hu \& Bentler, 1999), and (4) AGFI, whereas a value of above 0.80 shows an adequate fit of model (MacCallum \& Hong, 1997). So the results output extracted through AMOS are as follows; $\chi 2 / \mathrm{df}=1.651$, RMSEA $=0.042$, GFI $=0.915$, and AGFI $=0.891$, so this shows the goodness of fit to the model. Second, the incremental fit indexes measures includes "Normed Fit Index (NFI), the Incremental Fit Index (IFI), the Comparative Fit Index (CFI) and Relative Fit Index (RFI). The extracted value of all these fit indexes should be $>$ than the required value of 0.90 ( $\mathrm{Hu}$ and Bentler, 1999). The results output extracted via $\mathrm{AMOS}$ is as follow; $\mathrm{NFI}=0.954$, $\mathrm{RFI}=0.940, \mathrm{CFI}=0.988$, IFI, 0.981, and $\mathrm{TLI}=$ 0.975. Also, the Parsimonious Adjusted measures contain the Parsimony Comparative Fit Index (PCFI), the Parsimonious Normed Fit Index (PNFI) and the Parsimonious Goodness of Fit Index (PGFI). It is required that value of PCFI, PNFI and PGFI must be greater 0.50 for a good model fitness (Hu \& Bentler, 1999). The AMOS output results extracted are as follows; PCFI $=0.834$, PNFI $=0.765$, and PGFI $=0.718$. Overall, the above mention results shown that the structure of the proposed model of this efficiently describes the inter-link between constructs (Hair et al., 2011; Hair et al., 2014).

\subsubsection{Hypotheses results}

Structural Equation Modeling was used to test the hypothesized relationships, all the interlinked path coefficients. The potential multicollinearity concerns of the data set was tested via IBM-SPSS25. All the extracted output results of Variance inflation Factor (VIF) values range from 1.124 to 1.877 , i.e. quite below the required threshold value of 3.0, which revealed that model will not be affected by multicollinearity issue (see Table 3 ). The hypotheses results output shown that level of ISO certification awareness had positive effect on perceived quality $(\beta=0.472, \mathrm{t}=9.633, \mathrm{p}<0.01)$ so H1 was supported, level of ISO certification awareness also had positive relationship with brand image $(\beta=0.473, \mathrm{t}=6.391, \mathrm{p}<0.01)$ so $\mathrm{H} 2$ was supported. H3 was also supported because perceived quality had positive effect on brand image $(\beta=0.479, \mathrm{t}=4.553, \mathrm{p}<0.01)$. Perceived quality had positive effect on brand attitude $(\beta=0.450, \mathrm{t}=4.885, \mathrm{p}<0.01)$ so supported H4, Also perceived quality had positive effect on purchase intention $(\beta=0.486, \mathrm{t}=4.781, \mathrm{p}<0.01)$ so supported H5. Lastly, brand image also had positive effect on $(\beta=0.210, t=1.898, p<0.05)$ so supported H6, moreover the brand image had positive effect on purchase intention $(\beta=0.159, \mathrm{t}=$ 4.553, $\mathrm{p}<0.05)$ so supported H7. All the direct hypotheses accepted and findings to developed hypotheses (See Table 4 for details). 
Additionally, also explained the forecasting power of (R2) for each endogenous construct of this study. Predictably, the (R2) value explained the percentage of total variance in the endogenous construct caused by exogenous construct. The results output revealed that $40 \%$ of the total variance in perceived quality and $51 \%$ in brand image caused by level of ISO certification awareness. Second, $43 \%$ of total variance in brand attitude caused by level of ISO certification awareness, perceived quality and brand image. Third, $49 \%$ of variance in purchase intention explained by level of ISO certification awareness, perceived quality and brand image in consumer purchase intention. Whereas, the values required for (R2) were above the threshold or recommended value of $10 \%$ suggested by (Falk \& Miller, 1992).

Table 4. Results of Hypotheses

\begin{tabular}{|c|c|c|c|c|c|}
\hline Causal Path & $\begin{array}{l}\text { Standardized } \\
\text { Estimate }\end{array}$ & S.E. & C.R. & $\begin{array}{l}\mathrm{P} \text { - } \\
\text { value }\end{array}$ & Relationship \\
\hline $\begin{array}{l}\text { Perceived Quality } \leftarrow \text { ISO Certification } \\
\text { Awareness }\end{array}$ & 0.472 & 0.049 & 9.633 & 0.000 & Supported \\
\hline $\begin{array}{l}\text { Brand Image } \leftarrow \text { ISO Certification } \\
\text { Awareness }\end{array}$ & 0.473 & 0.074 & 6.391 & 0.000 & Supported \\
\hline Brand Image $\leftarrow$ Perceived Quality & 0.479 & 0.105 & 4.552 & 0.000 & Supported \\
\hline Brand Attitude $\leftarrow$ Perceived Quality & 0.450 & 0.156 & 2.885 & 0.004 & Supported \\
\hline Purchase Intention $\leftarrow$ Perceived Quality & 0.486 & 0.102 & 4.781 & 0.000 & Supported \\
\hline Brand Attitude $\leftarrow$ Brand image & 0.210 & 0.110 & 1.898 & 0.048 & Supported \\
\hline Purchase intention $\leftarrow$ Brand Image & 0.159 & 0.067 & 2.389 & 0.017 & Supported \\
\hline Structural Model & \multicolumn{5}{|c|}{ Cut-off Value } \\
\hline Model Fit Statistics & \multicolumn{5}{|c|}{$\begin{array}{l}\text { Chi-square }=132.048 \\
\text { d.f }=80 \\
\text { p-value }=0.000\end{array}$} \\
\hline Absolute Fit Indexes & \multicolumn{3}{|c|}{$\begin{array}{l}\text { Normed Chi-Square }= \\
1.651 \\
\text { RMSEA }=0.043 \\
\text { GFI }=0.915 \\
\text { AGFI }=0.891\end{array}$} & \multicolumn{2}{|c|}{$\begin{array}{l}1.0-3.0 \\
<0.08 \text { good fit } \\
>0.90 \\
>0.80\end{array}$} \\
\hline Incremental Fit Indexes & $\begin{array}{l}\mathrm{NFI}=0.954 \\
\mathrm{IFI}=0.981 \\
\mathrm{CFI}=0.988 \\
\mathrm{TLI}=0.975 \\
\mathrm{RFI}=0.940\end{array}$ & & & $\begin{array}{l}>0 \\
>0 \\
>0 \\
>0 \\
>, c\end{array}$ & $\begin{array}{l}90 \\
90 \\
90 \\
90 \\
90\end{array}$ \\
\hline Parsimonious Adjusted Indexes & $\begin{array}{l}\text { PCFI }=0.834 \\
\text { PNFI }=0.765 \\
\text { PGFI }=0.718\end{array}$ & & & $\begin{array}{l}>0 \\
>0 \\
>0\end{array}$ & \\
\hline
\end{tabular}

** $\mathrm{p}<0.01 . * \mathrm{p}<0.05$

\subsubsection{Testing the Mediation Effect}

Study measure five mediation relationship among the constructs via Maximum Likelihood Estimation (MLE) bootstrapping process to measure mediational effect with $95 \%$ confidence interval and biased-corrected confidence interval using 1000 bootstrap sample (Awang, 2015; Awang et al., 2018). It has been revealed that perceived quality partially mediate the relationship 
between ISO certification awareness and brand image because direct and indirect effects were significant $(\beta=0.223, \mathrm{p}<0.000)$. Second, perceived quality partially mediate the relationship between ISO certification awareness and brand attitude since both direct and indirect effect were significant $(\beta=0.212, \mathrm{p}<0.000)$. Third, perceived quality fully mediate the relationship between ISO certification awareness and purchase intention because direct effect is insignificant $(\beta=0.229$, $\mathrm{p}<0.000$ ). Fourth, brand image did not mediate the relationship between ISO certification and brand attitude because indirect effect was insignificant $(\beta=-0.064, p<0.180)$. Fifth, brand image fully mediate the relationship between ISO certification awareness and purchase intention because direct effect was insignificant but indirect is significant $(\beta=0.075, p<0.017)$.

\section{DISCUSSIONS}

The thematic analyses verify that middle management keen interest behind the adoption of integrated management system. Because that reduce the cost to maintaining ISO systems, increase the operational efficiency and concern focus continual improvement effectively evaluate and complex operational activities related paperwork reduce, the time utilization and working efficiency of employees increase. Because noise causes by series of audit eliminate and distortion during task performance cause audit staff reduce to 1 time from 3 times. One deficiency of integration adoption is resistance to change by employees, every procedure, practices, Duties and responsibilities revise and employees show resistance to change. But institution like "Engro food" device the culture of continuous improvement so it was easy for them to adopt the integration management system. The ISO systems information use in marketing activities to enhance customer confidence, and positive buying intention for brand.

Quantitative data analysis concluded that ISO system awareness among customers have positive influence on perceive quality of brand and the findings similar to the research study of (Nuland, 1990; Wu, 2011). Second, ISO certification directly influence the brand image this finding unique in sense with previous literature because it is evidenced that ISO certification awareness has indirect influence on brand image through perceived quality (Richardson, 1994; Wu \& Jang, 2014). The results revealed that the perceive quality is mediator in ISO certification awareness but have direct relations as well with brand image which was not evidence in previous studies and that is new contribution to the literature. Furthermore, both perceive quality have a direct or positive effect on brand attitude but brand image have insignificant effect on brand attitude which was not link with previous research findings of direct studies. Because previous studies revealed that brand attitude positively shaped by brand image and it effect consumer opinion about the ultimate elaboration towards product (Han, 1989; Wu \& Jang, 2014). Consumer purchase intention got positive effect when consumer have a preferred image of the brand and better perceived quality over its competitors have a positive intention of buying the product in future also match with literature (Wu \& Jang, 2014).

\section{CONCLUSION}

Study develop a new conceptual model which is the integration of two models tested separately in two different fields such as management and marketing context. This model is new contribution to both marketing and management literature. Previous study conceptual model explain the causal relationship between ISO certification awareness and purchase intention and this relationship mediate by perceive quality, brand image, brand attitude and brand preference (Wu \& Jang, 2014). This study export ISO integrated management model from architectural management field (Peng \& Kwang, 2011). The purpose behind this integrated model is that previous study not deeply investigates the ISO certification related concerns and just checks the customer view about the ISO certification. But this study evaluate that not only QMS 9001:2008 certification effect consumer 
behavior but also EMS 14001, OHSAS 18001 also affect the consumer behavior. Employees are the major customer of brand in FMCG consumption. Present study investigates the Consumer awareness about the ISO certification and also middle management perceptive about the adoption of integration certifications and influence of this certifications on the consumer intention towards brand attitude and purchase intention. The results concluded that by the Integration adoption of ISO certifications enhance the middle management work efficiency and also the need of ISO certifications integration with the marketing strategies of the organization. ISO certifications are always discuss in managerial concern of organization such as management of product quality, enhancement of environmental performance, health \& safety issues of workers but the second and more concern effect of these systems on the behavior of consumer which have to still address by the organizations.

\section{Managerial Implications}

ISO certifications influence limited to management of quality, environment, health \& safety issues. Here need is to integrate the management of ISO systems with marketing affords of the organization. When marketing efforts of firm include the information about the ISO certification it will enhance the perceive quality of product, brand image, brand attitude, and ultimately improve purchase intention.

\section{Research limitation and future research}

Study investigate the subject matter of study more deeply with limited resources, inefficiency may remain. The research participants were the worker of dairy product manufacturing industry those have knowledge about ISO certifications so this finding may not generalized on all population. So conceptual model may need to be further investigation and testing. Study use "Engro food" as research objects, therefore different organizations and sectors come up with distinguish research findings. So model may test in different industrial context.

\section{ACKNOWLEDGMENT}

This work is supported by Internal Grant Agency (IGA) of Tomas Bata University in Zlín, the Czech Republic, under project No. IGA/FAME/ 2021/009.

\section{REFERENCES}

Aaker, D. A. (1991). Managing brand equity. New York, NY: The Free Press.

Ajzen, I., \& Fishbein, M. (1980). Understanding attitudes and predicting social behavior. Englewood Cliffs, NJ: Prentice Hall.

Ajzen, I., \& Driver, B. L. (1991). Prediction of leisure participation from behavior, normative and control beliefs: An application of the theory of planned behavior. Leisure Sciences, 13(3), 185-204.

Aaker, D. A. (1996a). Measure brand equity across products and markets. California Management Review, 38(3), 102-120.

Aaker, D. A. (1996b). Building strong brands. New York, NY: The Free Press.

Anderson, J. C., \& Gerbing, D. W., (1988). Structural equation modeling in practice: a review and recommended two-step approach. Psychol. Bull. 103, 11-23.

Awang, Z. (2015). SEM Made Simple: A Gentle Approach to Learning Structural Equation Modelling. Bandar Baru Bangi, MPWS Rich Resources.

Awang, Z., Afthanorhan, A., Mohamad, M., \& Asri, M. A. M. (2015). An evaluation of measurement model for medical tourism research: the confirmatory factor analysis approach. International Journal of Tourism Policy, 6(1), 29-45.

Awang, Z, Lim, SH., \& Zainudin, NFS. (2018). Pendekatan Mudah SEM- Structural Equation Modelling. Bandar Baru Bangi, MPWS Rich Resource

Biel, A. L. (1992). How brand image drives brand equity. Journal of Advertising Research, 32(6), 6-12.

Blackwell, R. D., Miniard, P. W., \& Engel, J. F. (2001). Consumer behavior (9th ed.). New York, NY: Harcourt College Publishers. 
Bellizzi, J. A., Krueckeberg, H. F., Hamilton, J. R., \& Martin, W. S. (1981). Consumer perceptions of national, private, and generic brands. Journal of Retailing, 57(4), 56-70.

Brucks, M., \& Zeithaml, V. A. (1991). Price and brand name as indicators of quality dimensions. Cambridge, M A: Marketing Science Institute, 91-130.

Conti, T. (1999). Vision 2000: Positioning the new ISO 9000 standards with respect to total quality management models. Total Quality Management \& Business Excellence, 10(4/5), 454-464.

Chinen, K., Jun, M., \& Hampton, G. M. (2000). Product quality, market presence, and buying behavior: Aggregate images of foreign products in the U.S. Multinational Business Review, 8(1), 29-38.

Chowdhury, J., Reardon, J., \& Srivastava, R. (1998). Alternative model of measuring store image: An empirical assessment of structured versus unstructured measures. Journal of Marketing Theory and Practice, 6(2), 72-84.

Dodds, W. B., Monroe, K. B., \& Grewal, D. (1991). Effects of price, brand, and store information on buyers' product evaluation. Journal of Marketing Research, 28(3), 307-319.

Elmuti, D. (1996). World-class standards for global competitiveness: An overview of ISO 9000. Industrial Management, 38, 5-9.

Engel, J. F., Blackwell, R. D., \& Miniard, P. W. (1995). Consumer behavior (8th ed.). Forth Worth, TX: Dryden Press.

Falk, R. F., Miller, N. B., (1992). A Primer for Soft Modeling. University of Akron Press.

Fishbein, M. (1963). An investigation of the relationship between beliefs about an object and attitude toward that object. Human Relations, 16(2), 233-239.

Fishbein, M. I., \& Ajzen, I. (1975). Belief, attitude, intention and behavior: An introduction to theory and research. Reading, MA: Addison-Wesley.

Fornell, C., \& Larcker, D. F., (1981). Evaluating structural equation models with unobservable variable and measurement error. Journal of Marketing Research. 39-50.

Gotzamani, K. (2010). Results of an empirical investigation on the anticipated improvement areas of the ISO 9001:2000 standard. Total Quality Management \& Business Excellence, 21(6), 687-704.

Grewal, D., Krishnan, R., Baker, J., \& Borin, N. (1998). The effect of store name, brand name and price discounts on consumers' evaluations and purchase intentions. Journal of Retailing, 74(3), 331-352.

Grewal, D., Monroe, K. B., \& Krishnan, R. (1998). The effect of price-comparison advertising on buyers' perceptions of acquisition value, transaction value and behavioral intentions. Journal of Marketing, 62(2), 46-59.

Griffith, A. (1995). The current status of Environment Management System in construction. Engineering, Construction and Architectural Management, 2(1), 5-16.

Hair, J. F., Sarstedt, M., Hopkins, L., \& Kuppelwieser, V. G. (2014), "Partial least squares structural equation modeling (PLS-SEM)", European Business Review.

Hair, J. F. Ringle, C. M., \& Sarstedt, M. (2011). PLS-SEM indeed a silver Bullet. J. Market. Theory Practice. 19(2), 139-152.

Han, C. (1989). Testing the role of country image in consumer choice behaviour. European Journal of Marketing, 24(6), 24-40.

Higie, R., \&. (1991). Using recall and brand preference to evaluate advertising effectiveness. Journal of advertising research, 13(2), 56-63.

Hooper, D., Coughlan, J., \& Mullen, M. (2008). Structural equation modelling: guidelines for determining model fit. Electr. J. Bus. Res. Methods. 4 (1), 53-60.

Hu, L. T., \& Bentler, P. M. (1999). Cutoff criteria for fit indexes in covariance structure analysis: conventional criteria versus new alternatives. Structural. Equation Modeling. Multidisciplinary Journal. 6 (1), 1-55.

Intertex (2020). Using ISO 9001 or ISO 14001 to Gain a Competitive Advantage. Retrieved from www.intertek sc.com.

ISO (2013). ISO Certifications, Retrieved from www.iso.org: http//www.iso.org/iso/standards/management system

Janda, S., Trocchia, P. J., \& Gwinner, K. P. (2002). Consumer perceptions of Internet retail service quality. International Journal of Service Industry Management, 13(5), 412-431.

Kaizen Consulting Group (2013). www.kcg.com.sg/: http://www.kcg.com.sg/9001/html. Retrieved from (2013, December 10). 
Keller, K. L. (1993). Conceptualizing, measuring, and managing customer-based brand equity. Journal of Marketing, 57(1), 1-22.

Lin, L. H., \& Lu, I. Y. (2006). Product quality and product innovation: An empirical study of the global automotive industry. Total Quality Management \& Business Excellence, 17(2), 141-147.

Low, S. P. (1998). ISO 9000 and the Construction Industry: Practical Lessons. Chandos Publishing, Oxford, England.

Lane, V., \& Jacobson, R. (1995). Stock market reactions to brand extension announcements: The effects of brand attitude and familiarity. Journal of Marketing, 59(1), 63-77.

Lam, S. W., Low, C. M., \& Teng, W. A. (1994). ISO 9000 in Construction. McGraw-Hill Book Co., Singapore.

MacCallum, R. C., \& Hong, S. (1997). Power analysis in covariance structure modeling using GFI and AGFI. Multivariate Behavior Research. 32 (2), 193-210.

Monroe, K. (1990). Pricing: Making profitable decisions.

Morris, J. D., Woo, C., Geason, J. A., \& Kim, J. (2002). The power of affect: Predicting intention. Journal of Advertising Research, 43(3), 7-17.

Monroe, K. B., \& Krishnan, R. (1985). The effect of price on subjective product evaluations. In J. Jacoby \& J. Olson (Eds.), Perceived quality (pp. 209-232). Lexington, MA: Lexington Books.

MacKenzie, S. B., Lutz, R. J., \& Belch, G. E. (1986). The role of attitude toward the ad as a mediator of advertising effectiveness: A test of competing explanations. Journal of Marketing Research, 23(2), $130-143$.

Nuland, Y. (1990). The common language for 12 countries. Quality process. 23(6), 40-41.

Nunnally, J. C. (1978). Psychometric theory. New York, NY: McGraw-Hill.

Nguyen, N., \& LeBlanc, G. (1998). The mediating role of corporate image on customers' retention decisions: An investigation in financial service. The International Journal of Bank Marketing, 16(2), 52-65.

Oliver, R. L. (1999). Whence consumer loyalty? Journal of Marketing, 63(Special issue), 33-44.

Podsakoff, P. M., \& Organ, D. W. (1986). "Self-reports in organizational research: problems and prospects", Journal of Management, Vol. 12 No. 4, pp. 531-544.

Podsakoff, P. M., MacKenzie, S. B., Lee, J. Y., \& Podsakoff, N. P. (2003). Common method biases in behavioral research: a critical review of the literature and recommended remedies. J. Appl. Psychol. $88(5), 879$.

Poksinska, B., \& Dahlgaard, J. J. (2003a). ISO 9001: 2000 - the emperor's new clothes. European Quality, 10(3), 32-43.

Poksinska, B., \& Dahlgaard, J. J. (2003b). Implementing ISO 14000 in Sweden: Motives, benefits and comparisons with ISO 9000. International Journal of Quality and Reliability Management, 20(5), 585-606.

Punj, G. N., \& Hillyer, C. L. (2004). A cognitive model of customer-based brand equity for frequently purchased products: Conceptual framework and empirical results. Journal of Consumer Psychology, $14(1 / 2), 124-131$.

Pheng, K. (2005). ISO 9001, ISO 14001, OHSAS 18001 management systems: integration, Cost and Benefits for Construction Companies. Architectural science review, 48, 145-152.

Payner, P., \& Porter, L. T. (1991). BS 5750/ISO 9000 - The experience of small and medium-sized firms. International Journal of Quality \& Reliability Management, 8(6), 16-28.

Richardson, P. D. (1994). Extrinsic and extrinsic cue effect on perceptions of store brand equity. Journal of Marketing Research, 58(4), 28-36.

Srinivasan, V. (1979). Network models for estimating brand-specific effects in multi-attribute marketing models. Management Science, 25(1), 11-21.

Singels, J., Ruel, G., \& Water, H. (2001). ISO 9000 series certification and performance. International Journal of Quality and Reliability Management, 18(1), 62-75.

Smith, R. E., \& Swinyard, W. R. (1982). Information response models: An integrated approach. Journal of Marketing, 46(1), 81-93.

Solomon, M. R. (2002). Consumer behavior: Buying, having, and being (5th ed.). Upper Saddle River, NJ: Prentice-Hill.

Schniederjans, M. J., Cao, Q., \& Olson, J. R. (2004). Consumer perceptions of product quality: Made in China. The Quality Management Journal, 11(3), 8-19. 
Vloeberghs, D., \& Bellens, J. (1996). Implementing the ISO 9000 standards in Belgium. Quality Progress, 29(6), 43-48.

Whitelaw, K. (2004). ISO 14001. (S. e. 2004, Ed.) Burlington: Elsevier ltd.

Wu, S-I., \& Chen, J. H. (2011). Comparison between manufacturing companies that are ISO certified and those that are not certified using performance measurement model. Total Quality Management \& Business Excellence, 22(8), 869-890.

Wu S-I., \& Jang, J-Y. (2014). The impact of ISO certification on consumers' purchase intention, Total Quality Management \& Business Excellence, 25:3-4, 412-426, DOI: 10.1080/14783363.2013.776770

Wang, Y., Lo, H. P., \& Hui, Y. V. (2003). The antecedents of service quality and product quality and their influences on bank reputation: Evidence from the banking industry in China. Managing Service Quality, 12(1), 72-83.

Yu, C. M. J., Wu, L. Y., Chiao, Y. C., \& Tai, H. S. (2005). Perceived quality, customer satisfaction, and customer loyalty: The case of Lexus in Taiwan. Total Quality Management \& Business Excellence, 16(6), 707-719.

Yang, C. C. (2011). Identification of customer delight for quality attributes and its applications. Total Quality Management \& Business Excellence, 22(1), 83-98.

Zeithaml, V. A. (1988). Consumer perception of price, quality and value: A means-end model and synthesis of evidence. Journal of Marketing, 52(3), 2-22.

Zins, A. H. (2001). Relative attitudes and commitment in customer loyalty models: Some experience in the commercial airline industry. International Journal of Service Industry Management, 12(3), 269-294.

Zelnik, M., Maletic, M., Maletic, D., \& Gomiscek, B. (2012). Quality management systems as a link between management and employees. Total Quality Management \& Business Excellence, 23(1), $45-62$. 